九州大学学術情報リポジトリ

Kyushu University Institutional Repository

\title{
Impact of Agricultural Income Risk on Farm Management : An Empirical Analysis from the Southwest of China
}

Wang, Zhigang

Renmin University of China

Yutaka, Tomoyuki

Faculty of Agriculture, Kyushu Unviersity

Fukuda, Susumu

Faculty of Agriculture, Kyushu Unviersity

Kai, Satoshi

Faculty of Agriculture, Kyushu Unviersity

https://doi.org/10.5109/4680

出版情報: 九州大学大学院農学研究院紀要. 50 (2)，pp.685-692，2005-10-01. Faculty of Agriculture, Kyushu University

バージョン：

権利関係 : 
J. Fac. Agr., Kyushu Univ., 50 (2), 685-692 (2005)

\title{
Impact of Agricultural Income Risk on Farm Management: An Empirical Analysis from the Southwest of China
}

\author{
Zhigang WANG ${ }^{1}$, Tomoyuki YUTAKA, Susumu FUKUDA \\ and Satoshi KAI* \\ Laboratory of Agricultural Marketing, Division of Industrial Organization of \\ Agribusiness, Department of Agricultural and Resource Economics, \\ Kyushu University, Fukuoka 812-8581, Japan \\ (Received June 30, 2005 and accepted July 26, 2005)
}

\begin{abstract}
This paper is to estimate the risk level of agricultural income for each household, to analyze the impact of socioeconomic variables on the households' attitudes towards the risk level, and to explain the conditions of the new-technology adoption with the variables including risks, especially pointing out the impact of the risk level on adoption of new-technology on the use of fertilizer.

According to the above analysis, we found that the agricultural income risk had no evident influence on the new-technology adoption and the use of fertilizer for each household, which suggested that the households in china were risk-neutral, and under the disaster level income of World Bank standard, the income risk for each peasant household nearly presents normality distribution; while under the Chinese National standard, it is prone to low-level risk. In summary, we could not find the conclusion that risk had significant impact on households' management.
\end{abstract}

\section{INTRODUCTION}

Since the failure of the industrialization strategy emerged in the 1980s, many development economists began to rethink the price of the strategy - the sacrifice of agriculture, and reached a new realization of the importance of agriculture. With microeconomics was suggested as the basis of macroeconomics, more and more development economists focused their research on the individual behavior in developing countries (Wenping Peng, 2002). Compared to developed countries, the number of farmers in developing countries is much larger, which has been hampering economic development. Therefore, the farmers, especially the farmers' behavior, are becoming a hotspot of economic development study.

Roumasset (1976) concluded that farmers were risk-aversion, their behavior followed the safety first rules of thumb and Ellis (1998) described the farmers' behavior under the 'safety-first' principle. What is the attitude of farmers on risk in China? Are they the traditional risk-aversion or will they diversify under different circumstances, such as socioeconomic factors and income levels?

In this paper, we manage to develop a model to test the risk attitudes of Chinese peasant households. The structure of this paper is as follows: in the second section, we

\footnotetext{
1 School of Agricultural Economics and Rural Development, Renmin University of China, China.
}

* Corresponding author (E-mail: satokai@agr.kyushu-u.ac.jp) 
provide an overview of the peasants risk theory and propose a hypothesis; In the third section, we measure the peasant households' risk level based on the 'safety-first' principle; In the fourth section, we introduce demographic and socioeconomic factors affecting peasant households' risk attitudes and do a quantitative analysis of the risk decision-making mechanism; In the fifth section, we analyze how the factors (including the risk level) influence the peasant households' application of new-technology and use of inputs; In the final section, we point out the characteristics of peasant households' risk-taking as a result, above all we provide some suggestions.

\section{REVIEW OF THE PEASANT HOUSEHOLDS' RISK-TAKING THEORY AND HYPOTHESES}

In his work PEASANT ECONOMICS, Ellis (1998) gave an economic definition of peasants -Peasants are farm householders, with access to their means of livelihood in land, utilizing mainly family labor in farm production, always located in a larger economic system, but fundamentally characterized by partial engagement in markets which tend to function with a high degree of imperfection. As a unit engaged in production and consumption, peasant household encounters various risks. Wenping Peng (2002) thought mainly four factors induced their risks: First, natural disaster, such as climate, plant diseases and insect pests; second, price fluctuation; third, the social relationship in rural areas of developing countries, such as the uneven distribution of land and capital; the final is the government's action and certain occasional incidences. Jiujie Ma et al. (2003) attributed the peasant households' risk to natural disaster, health problem, economic activities, society, destruction of resources and contamination of environment. Peasant households' abilities to deal with risks are fragile, which is essential for diffusion of new-technology in most developing countries.

Until now, there are mainly two views about the peasant households' behavior. One is W. Schultz's 'rational small farmer' theory; the other is Ellis's 'safety-first' principle. In the safety-first principle, it assumes that the individual's objective is to minimize the probability of experiencing an income fall below some initial level. The safety-first risk formula derived by Roy (1952) was used empirically by Shahabuddin et al. (1988), Parikh and Bernard (1988). Here we can minimize the probability that the income falls below a specified disaster level $\left(d^{*}\right)$ as follows,

$$
\operatorname{MinP}\left(\pi<d^{*}\right) \text {, or } \operatorname{MinF}\left(d^{*}\right)
$$

Where $P$ refers to probability and $F$ is the cumulative distribution function of the ith prospect. Operationally, the formula is expressed as:

$$
\operatorname{Minimize}\left(\frac{d^{*}-\mu}{\sigma}\right)
$$

Where $\mu$ is the expected income, $d^{*}$ is the disaster level income, and $\sigma$ is the standard variance of household's income. The relative magnitudes of the variables $d^{*}$ and $\mu$ determine whether the farm family is forced to gamble $\left(d^{*}>\mu\right)$, or to adopt reducing the risk and increasing expected income $\left(d^{*}<\mu\right)$. 
We get a hypothesis immediately from the safety-first principle.

$H 1$ : if the disaster level of income is higher than expected income, a peasant household may be forced to adopt new-technology or increasing inputs so that the gamble pays off and his realized income turns out to be higher than disaster-level income; vice versa.

Pratt (1964) and Arrow (1970) hypothesized in the context of expected utility theory that absolute risk aversion may diminish the disaster level income. Risk-aversion may decline rapidly in the neighborhood of subsistence income. Once the peasant households' expected incomes are higher than the disaster level of income, risk-aversion sets in and the tendency to gamble with one's wealth or current income (when it is above disaster level) tends to diminish. This plausible hypothesis was tested by Parikh and Bernard (1988) with the Bangladesh data.

Is the hypothesis $\mathrm{H} 1$ rational in China? The impact of risk on decision makers in their choice of adoption of new-technology, fertilizer use will be analyzed empirically in the following paragraphs.

\section{COMPUTATION OF DISASTER LEVEL INCOME AND EXPECTED INCOME FOR EACH HOUSEHOLD}

The data used in this paper were obtained from the local Statistics Agency of FenDu County, TongNan County and HeChuan County, belonging to the ChongQing municipality directly under the Central Government, the southwest of China. The sample covers FenDu and TongNan County, with ten villages for each county, and five villages in HeChuan County, with ten households in each village. In total, the sample number is 250 , coming from 25 villages of three counties. The samples were selected at random.

The formula of computation for disaster income level for each household is based on Roumasset's (1976), Ashok Parikh and Andrew Bernard's (1988) principle:

$$
\mathrm{d}=\mathrm{MCN}+\mathrm{UD}-\mathrm{LA} / 15-\mathrm{OFI}=\mathrm{MCC}\left[\mathrm{FSZ}-0.5^{*}(\mathrm{NWCH})\right]+\mathrm{UD}-\mathrm{LA} / 15-\mathrm{OFI}
$$

Where MCN are the Minimum consumption needs obtained from MCC (Minimum consumption calories) per person exchanged into Chinese Currency Unit (RMB), FSZ is family size and NWCH are numbers of children (family size treats all as adult), UD is urgent debt, LA are livestock and business assets in value terms, and OFI is trade income and industrial income, namely non-agricultural income. Here we adopt two standards to compute the disaster level income. One is the Chinese national disaster level income standard $(\mathrm{MCCC}=625 \mathrm{RMB})$ and the other is the lowest level income standard of World Bank (MCCW=865 RMB). Under the two standards, formula (1) can be expressed separately as:

$$
\begin{aligned}
& \mathrm{dc}=\mathrm{MCCC} *\left[\mathrm{FSZ}-0.5^{*}(\mathrm{NWCH})\right]+\mathrm{UD}-\mathrm{LA} / 15-\mathrm{OFI}(\text { Chinese National standard }) \\
& \left.\mathrm{dw}=\mathrm{MCCW} * \mathrm{FSZ}-0.5^{*}(\mathrm{NWCH})\right]+\mathrm{UD}-\mathrm{LA} / 15-\mathrm{OFI}(\text { World Bank standard })
\end{aligned}
$$

Based on Parikh and Bernard's (1988), the expected income for each household defined $\mu_{i j}$ as: 
Table 1. Frequency distribution of safety-first measure of risk-aversion

\begin{tabular}{|c|c|c|c|c|}
\hline & \multicolumn{2}{|c|}{$\mathrm{RC}$} & \multicolumn{2}{|c|}{ RW } \\
\hline & -30.04 & 1 & -3.88 & 7 \\
\hline & -25.65 & 0 & -2.88 & 9 \\
\hline & -21.26 & 0 & -1.87 & 24 \\
\hline & -16.87 & 2 & -0.87 & 78 \\
\hline & -12.48 & 5 & 0.14 & 79 \\
\hline & -8.09 & 37 & 1.14 & 37 \\
\hline & -3.70 & 201 & 2.15 & 12 \\
\hline & 0.68 & 4 & 3.15 & 4 \\
\hline Sample count & \multicolumn{2}{|c|}{250} & \multicolumn{2}{|c|}{250} \\
\hline Total & \multicolumn{2}{|c|}{-610.82} & \multicolumn{2}{|c|}{50.35} \\
\hline Mean & \multicolumn{2}{|c|}{-2.44} & \multicolumn{2}{|c|}{0.20} \\
\hline Minimize & \multicolumn{2}{|c|}{-30.04} & \multicolumn{2}{|c|}{-3.88} \\
\hline Maximize & \multicolumn{2}{|c|}{5.07} & \multicolumn{2}{|c|}{4.16} \\
\hline Variance & \multicolumn{2}{|c|}{8.66} & \multicolumn{2}{|c|}{1.71} \\
\hline Standard variance & \multicolumn{2}{|c|}{2.94} & \multicolumn{2}{|c|}{1.31} \\
\hline Variance coefficient & \multicolumn{2}{|c|}{-1.20} & \multicolumn{2}{|c|}{6.49} \\
\hline
\end{tabular}

Resource: author.

$$
\begin{aligned}
\mu_{i j}= & (\text { VOWNZ + VRINZ })(1+\text { TOTDMG })-\text { SEEDQC }- \text { IRRC }- \text { FERTC - BULLC } \\
& - \text { PESTC - WAGEC - PLASC }
\end{aligned}
$$

We use value of output on owned (VOWNZ) and rented land (VRINZ) and adjust for crop damage to obtain the expected value of output. The variable TOTDMG is the weighted crop damage and this yields unexpected crop damage. From these, we excluded the cost of all purchased inputs, which are seed (SEEDQC), irritation (IRRC), fertilizer (FERTC), bullocks (BULLC), pesticides (PESTC), wages (WAGEC) and plastic (PLASC).

We use the foresaid disaster level income $\bar{d}_{i j}$ and expected income $\mu_{i j}$ to compute the risk-taking or risk-averting level for each household. The results are shown in table 1. We can see, under the Chinese National standard, the risk level is relatively near the low level of risk and does not appear standard normality distribution; by contraries, under the World Bank standard, it is relatively even, and appears standard normality distribution, i.e.

$$
R_{i j}=\frac{\bar{d}_{i j}-\mu_{i j}}{\sigma_{i}}, i=1,2, \ldots 25, j=1,2, \ldots 250
$$

\section{IMPACT OF DEMOGRAPHIC AND SOCIOECONOMIC VARIABLES ON INCOME RISK FOR EACH HOUSEHOLD}

We use socioeconomic variables to regress the risk attitude $R$. As the villages of plain, foothill and mountain are in three environmental zones; the incomes for households in different areas should have significant deviation, which can be tested with dummy variables.

The socioeconomic variables used are: labors engaged in agriculture, labors engaged in non-agriculture, agricultural capital, i.e. the fixed capital put into agriculture, 
non-agricultural capital, family size, the education or literature level of the household's head and the above-mentioned dummy variables of the three environmental indicators. The risk-taking equation will have the following form:

$$
R_{i j}=c o n s \tan t+b_{1} E D N F_{i j}+b_{2} F S Z_{i j}+b_{3} A G C P_{i j}+b_{4} N A G C P_{i j}+b_{5} N A G I N_{i j}+b_{6} A R E A_{i j}+\varepsilon_{i j}
$$

Where $R_{i j}$ is the risk level of the jth household of the ith village. $E D N F_{i j}$ is the cumulative of the educated years of the family members. $F S Z_{i j}$ is the family size. $A G C P_{i j}$ is the capital put into agriculture, $N A G C P_{i j}$ is the capital put into non-agricultural sector, $N A G I N_{i j}$ is the non-agricultural income $A R E A_{i j}$ are the area for agriculture. With expected signs $b_{1}$ uncertain, $b_{2}>0, b_{3}<0, b_{4}$ uncertain, $b_{5}<0, b_{6}<0$.

The estimate of the equation is presented in table 2 . Under the disaster level income of Chinese National standard; the significant variables influencing $\mathrm{RC}$ are non-agricultural investment, non-agricultural income and area. All of them have a significantly negative correlation with the risk level for each household. While under the World Bank standard the variables significantly influencing RW are non-agricultural investment, family size and agricultural investment. When the non-agricultural investment and agricultural investment is larger, the agriculture income risk for each household is smaller; the family size larger, the risk larger. In a word, with different disaster level income, the impact of variables on risk level for each household varies. In both cases, the higher the disaster income level, the greater impact the agricultural investment and family size have on risk level for each household.

We found in table 2 that increasing the non-agricultural investment and non-agricultural income could improve households' risk-aversion ability. Furthermore, we found also in the table that the family planning program in order to control the family size could diminish the households' income risk.

Table 2. Estimation of income risk

\begin{tabular}{|c|c|c|c|c|}
\hline Variables & $\begin{array}{c}\text { RC Equation } \\
\text { Coefficient }\end{array}$ & $\begin{array}{c}\text { RC Equation } \\
\text { t Value }\end{array}$ & $\begin{array}{l}\text { RW Equation } \\
\text { Coefficient }\end{array}$ & $\begin{array}{c}\text { RW Equation } \\
\text { t Value }\end{array}$ \\
\hline EDNF & -0.0359 & 1.5997 & 0.0108 & 1.1738 \\
\hline FSZ & 0.2850 & 1.6353 & 0.3442 & 4.8240 \\
\hline AGCP & 0.0001 & 1.2369 & -0.0001 & 2.5632 \\
\hline NAGCP & -0.0021 & 9.7336 & -0.0002 & 1.8223 \\
\hline NAGIN & -0.0001 & 3.8497 & -0.0001 & 10.7178 \\
\hline AREA & -0.2734 & 2.6618 & 0.0094 & 0.2237 \\
\hline Constant & -1.1027 & 2.0782 & -0.4003 & 1.8427 \\
\hline & \multicolumn{2}{|c|}{0.3326} & \multicolumn{2}{|c|}{0.4322} \\
\hline Revised RR & \multicolumn{2}{|c|}{0.3162} & \multicolumn{2}{|c|}{0.4182} \\
\hline $\mathrm{R}$ & \multicolumn{2}{|c|}{0.5767} & \multicolumn{2}{|c|}{0.6574} \\
\hline Revised R & \multicolumn{2}{|c|}{0.5623} & \multicolumn{2}{|c|}{0.6467} \\
\hline DW Value & \multicolumn{2}{|c|}{1.2098} & \multicolumn{2}{|c|}{1.1749} \\
\hline AIC Statistics & \multicolumn{2}{|c|}{1162.1888} & \multicolumn{2}{|c|}{715.7381} \\
\hline
\end{tabular}

Resource: author. 


\section{MODEL INTEGRATING RISK IN NEW-TECHNOLOGY ADOPTION AND INPUT DECISIONS}

Peasants living in the rural areas of poor countries have to deal with not only the severe poverty but also the wide fluctuations of income. Thus, even when the mean income is above the disaster level income, its fluctuations can still throw enough threat on peasants' living and have great influence on the new-technology adoption. (Parikh and Bernard, 1988).

In this section, we run regression to reflect the significant role in new-technology adoption decisions using the $\mathrm{R}$ defined as independent variable and other variables: credit and expected output. We regress the use of fertilizer with $R$, variables of new-technology adoption decision and other related characteristics: family size and area. There we indicate the condition of new-technology adoption with the sum of area: (1) area covered with plastic; (2) area of machine-ploughed; (3) area of manual transplant; (4) area of machine planting. Input is the use of fertilizer. The results of the regression are presented in table 3 and table 4 .

Table 3 shows that the variables - education of the family member, expected income, landform, all have significantly positive correlation with the new-technology. adoption. While both RC and RW have no significant influence on new-technology adoption, i.e. new-technology adoption has no evident connection with the income risk for each household, which testifies that the peasant households are risk-neutral and confirms the H1. Furthermore, from table 4, we can infer that in equations FQA-RC and FQA-RW, the income risks have no evident influence on the use of fertilizer. That is a

Table 3. the impact of income risk on new-technology adoption

\begin{tabular}{|c|c|c|c|c|}
\hline Variables & $\begin{array}{c}\text { PLAS-RC } \\
\text { Equation } \\
\text { Coefficien }\end{array}$ & $\begin{array}{c}\text { PLAS-RW } \\
\text { Equation } \\
\text { t Value }\end{array}$ & $\begin{array}{l}\text { PLAS-RW } \\
\text { Equation } \\
\text { Coefficient }\end{array}$ & $\begin{array}{c}\text { PLAS-RW } \\
\text { Equation } \\
\text { t Value }\end{array}$ \\
\hline UD & 0.0001 & 1.9332 & 0.0001 & 2.2955 \\
\hline EDNF & 0.0167 & 2.4362 & 0.0193 & 2.7261 \\
\hline AGCP & 0.0000 & 0.2811 & 0.0000 & 0.0010 \\
\hline$\mu$ & 0.0002 & 3.5321 & 0.0001 & 3.1222 \\
\hline $\mathrm{RC}$ & 0.0043 & 0.2253 & & \\
\hline RW & & & -0.0688 & 1.3993 \\
\hline REGN & 0.7385 & 3.3207 & 0.7382 & 3.3575 \\
\hline CRGNDMF & 1.0083 & 5.7527 & 1.0528 & 5.9454 \\
\hline DRGNDMT & 0.2964 & 1.9525 & 0.3289 & 2.1511 \\
\hline Constant & -1.3176 & 4.2808 & -1.3342 & 4.3613 \\
\hline $\mathrm{RR}$ & \multicolumn{2}{|c|}{0.1815} & \multicolumn{2}{|c|}{0.1880} \\
\hline Revised RR & \multicolumn{2}{|c|}{0.1544} & \multicolumn{2}{|c|}{0.1610} \\
\hline $\mathrm{R}$ & \multicolumn{2}{|c|}{0.4261} & \multicolumn{2}{|c|}{0.4335} \\
\hline Revised R & \multicolumn{2}{|c|}{0.3929} & \multicolumn{2}{|c|}{0.4012} \\
\hline DW Value & \multicolumn{2}{|c|}{1.2335} & \multicolumn{2}{|c|}{1.2554} \\
\hline AIC Statistics & \multicolumn{2}{|c|}{643.4650} & \multicolumn{2}{|c|}{641.4947} \\
\hline
\end{tabular}

Resource: author. 
Table 4. the impact of income risk on the use of fertilizer

\begin{tabular}{|c|c|c|c|c|}
\hline Variables & $\begin{array}{c}\text { FQA-RC } \\
\text { Equation } \\
\text { Coefficient }\end{array}$ & $\begin{array}{c}\text { FQA-RC } \\
\text { Equation } \\
\text { t Value }\end{array}$ & $\begin{array}{c}\text { FQA-RW } \\
\text { Equation } \\
\text { Coefficient }\end{array}$ & $\begin{array}{c}\text { FQA-RW } \\
\text { Equation } \\
\text { t Value }\end{array}$ \\
\hline$\mu$ & -0.0571 & 2.9533 & -0.0592 & 2.9579 \\
\hline $\mathrm{RC}$ & 3.4122 & 0.4383 & & \\
\hline $\mathrm{RW}$ & & & -8.2171 & 0.4195 \\
\hline PAGR & $\cdots 40.6312$ & 1.5060 & 43.4101 & 1.5636 \\
\hline AREA & 43.3951 & 2.6715 & 43.6549 & 2.6730 \\
\hline PLAS & 70.6844 & 2.5867 & 70.1827 & 2.5600 \\
\hline REGN & 363.5387 & 3.9066 & 356.5509 & 3.8313 \\
\hline CRGNDMF & 502.8734 & 6.2859 & 509.9281 & 6.3326 \\
\hline DRGNDMT & 134.0494 & 1.9126 & 139.5056 & 1.9850 \\
\hline Constant & -278.8885 & 2.1916 & -283.8930 & 2.2400 \\
\hline $\mathrm{RR}$ & \multicolumn{2}{|c|}{0.4089} & \multicolumn{2}{|c|}{0.4089} \\
\hline Revised RR & \multicolumn{2}{|c|}{0.3892} & \multicolumn{2}{|c|}{0.3892} \\
\hline $\mathrm{R}$ & \multicolumn{2}{|c|}{0.6395} & \multicolumn{2}{|c|}{0.6395} \\
\hline Revised R & \multicolumn{2}{|c|}{0.6239} & \multicolumn{2}{|c|}{0.6239} \\
\hline DW Value & \multicolumn{2}{|c|}{1.3430} & \multicolumn{2}{|c|}{1.3437} \\
\hline AIC Statistics & \multicolumn{2}{|c|}{3641.1647} & \multicolumn{2}{|c|}{3641.1814} \\
\hline
\end{tabular}

Resource: author.

perfect evidence for peasant households' risk-neutral attitudes for agricultural income. However, expected income, area, new-technology area and dummy variables of landform are significantly correlated with the use of fertilizer.

\section{SUMMARY AND CONCLUSIONS}

In this paper, the process of cause and effect is: socioeconomic variables —risk level - area size of new-technology adoption - input of factors. The former brings forth the later. In the paper, we estimated the risk level of income for each household; we analyzed the impact of socioeconomic variables on the households' attitudes towards risk; then we explained the conditions of the new-technology adoption with the variables including risks. At last, we analyze the impact of risk and adoption of new-technology on the use of fertilizer.

Based on the above analysis, we found that the income risk had no evident influence on the new-technology adoption and the use of fertilizer for each household, which suggested that the households in china were risk-neutral, and under the disaster level income of World Bank standard, the income risk for each peasant household nearly presents normality distribution; while under the Chinese National standard, it was prone to low-level risk. In summary, we could not find the conclusion that risk had significant impact on households' management.

\section{REFERENCES}

Ashok Parikh and Andrew Bernard 1988 Impact of Risk on HYV Adoption in Bangladesh. Agricultural Economics, 2: 167-178 
F. Ellis 1988 Peasant Economics. Cambridge University Press

J. A. Roumasset 1976 Rice and risk: Decision Making among Low Income Farmers. North Holland, Amsterdam

Jiujie Ma and Yong Zhu 2003 Rural households' Risk Coping Strategies, Social Risk Management and Insurance: A Survey of Related Literatures. In "Proceedings of The Third Non-governmental Organization Forum on International Environmental Cooperation in China", Department of Agricultural Economics, Renmin University of China, pp. 136-141

J. Patt 1964 Risk aversion in the small and in the large. Econometrica, 32: 122-136

K. Arrow 1970 Essays in the Theory of Risk Bearing. Markham, Chicago, IL

Q. Shahabuddin, S. Mestelman and D. Feeny 1986 Peasant behavior towards risk and socio-economic and structural characteristics of farm households in Bangladesh. Oxford Economic Paper, 38: 122-130

Wenping Pen 2002 Peasants Economics: Frontier of Development Economics. Journal of Agricultural Economics (Chinese), Vol. 2002, 7: 59-63 